\title{
The Inconsistency of ICSID Awards Over Argentina
} Cases

\author{
M. Ya'kub Aiyub Kadir'1, Lena Farsia² \\ ${ }^{1}$ Faculty of Law, Syiah Kuala University, Indonesia.E-mail:m.yakub.akadir@unsyiah.ac.id \\ 2 Faculty of Law, Syiah Kuala University, Indonesia. E-mail: lena.farsia@unsyiah.ac.id
}

\author{
ARTICLE INFO \\ Keywords: \\ Argentina; Customary \\ International Law; \\ Economic Development; \\ ICSID Awards; \\ Investment \\ How to cite: \\ Kadir, M.Y.A., and \\ Farsia. L. (2020). The \\ Inconsistency of ICSID \\ Awards Over Argentina \\ Cases. Hasanuddin Law \\ Review, 6 (1): 1-24 \\ DOI: \\ 10.20956/halrev.v6i1.1844
}

\begin{abstract}
This paper discusses the inconsistency of International Centre for Settlement of Investment Disputes (ICSID) awards over an emergency situation in Argentina in 2001. Utilising a doctrinal methodology under Third World Approach to International Law (TWAIL) paradigm, this paper explores the argument set out in Argentina case in the first trial and its appeals, then makes an effort to find out the better and systematic argument for Argentina. Therefore, this paper contributes to factually understanding the different argument from two perspectives in ICSID proceedings which has been contested and herewith proposed a better formulated argument for the future of ICSID awards making by placing economic development in Third World States as a basis of argument. Hence this argument can be used for the similar cases in the ICSID in future.
\end{abstract}

\section{Introduction}

The purpose of foreign investments is economic growth, to decrease unemployment and transfer of knowledge. However, when many host states have not well prepared any supporting tools to reach such benefits, they might only get revenue from tax and cash benefit for particular elites of government. This situation was proven with the missing link of economic crisis and huge investment in Argentina, ${ }^{1}$ as Sornarajah stated that:

1 See the analyses of Foreign Direct Investment in Argentina in Daniel Chudnovsky and Andres Lopes, Foreign Investment and Sustainable Development in Argentina, Discussion Paper number 12, Working Group on Development and Environment in America, April 2008. 
[t]here is no empirical proof that a bilateral investment treaties do contribute to the economic development of developing countries. If they did then, of course, African would be a developed country simply because African states are very large practitioners of such treaties. $^{2}$

In similar sense, Francioni highlighted that "[d]enial of justice lies at the heart of the development of International Law on the treatment of aliens and of foreign investment" ${ }^{3}$ This has represented the picture of postcolonial world in looking at the fairness and equitable standard set out by the Organisation for Economic Co-operation and Development (OECD) report on September 2004 which is merely to protect foreign investors from the developed states. ${ }^{4}$ Such situation represents Argentina as a leading case $^{5}$ in justifying the people's interest and necessity reasons against positivistic international Investment Law that rooted from economic liberalism which is contested to socio-political reasoning. 6 Argentina has faced the worst economic crisis after the IMF suspended the disbursement of loan due to the failure of Argentina to comply

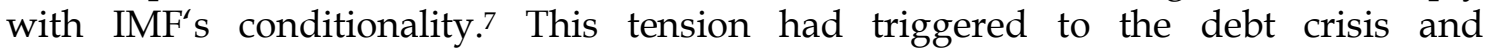
subsequently become economic crisis. ${ }^{8}$

Debt and investment are two correlated potential concern for economic development in postcolonial states. The economic relations in term of debt and investment become unchanged, even in following days, the TW states was begging for sustainable debt and investment to the colonial power regimes. ${ }^{9}$ In this case, Argentina has experienced economic crisis which was led by sovereign debt default. The existence of the IMF as the leading lending monetary club has become a dilemma for Argentina, when fulfilling its conditionality and its failure to be a prescription during economic crisis, resulted to the people crisis and also political crises which lead the state to become bankrupt. Such situation may represent the post-colonial states which faces an extreme situation of debt and monetary failure, then turn into investment failures that adversely impacted to the people and the sustainability of sovereign states. The debt failures were the first problem that made instability of states income and the compensation to pay to investor for their claims also gave a burden for Argentine budget. 10

2 Sornarajah, M “The Fair and Equitable Standard of Treatment: Whose Fairness? Whose Equity? In Federico Ortino et al. (2007) Investment Treaty Law, Current Issues II, Nationality And Investment Treaty Claims, Fair And Equitable Treatment In Investment Treaty Law, London: British Institute of International and comparative Law, p. 180.

3 Francesco Francioni, Access to Justice, Denial of Justice and international Investment Law, The European Journal of International Law (2009) Vol.20 no. 3, 2009, 729, http://ejil.oxfordjournals.org/ accessed on November 7, 2012.

4 Sornarajah, M, p. 180-181.

5 See Bishop R.Doak \& Luzi, Roberto Aguirre 'Investment Claims: First Lessons from Argentina' in Tod Weiler (2005) International Invesment Law And Arbitration: Leading Cases From The ICSID, NAFTA, Bilateral Treaties And Customary International Law, London: Cameron May, p. 425-469.

6 Sornarajah, M. (2004) the International Law on Foreign Investment, Cambridge: Cambridge University Press, p. 50- 65.

7 Federico Sturzenegger and Jeromin Zettle Meyer. (2007). Debt Defaults and Lessons from A Decade of Crises, the IMT press, p. 179.

8 See Hornbeck (2010) Argentina's Defaulted Sovereign Debt: Dealing with the "Holdouts", Congressional research service, January 21, 2010, www, crs.gov, accessed in 1 September 2011.

9 Francesco Francioni, Op. Cit, 729- 47.

10 Cesar Augusto Bunge and Diego Cesar Bunge, 'The Jose De Costa Rica Pact and the Calve doctrine', the University of Miami Inter-American Law Review, Vol. 16 No.1 (spring, 1984)pp. 13-52. 
The highly negative impacts of this crisis over its people which had increased the poverty over $20 \%$ and about $30 \%$ of population become unemployment. 11 Subsequently, mass demonstration over government and the resignation of president has implied the critical social political stability which could lead to the failure of state. Argentina imposed economic recovery policies in order to help their people under the economic crisis which indirectly affected to the breach of US-Argentina Bilateral Investment Treaty 1991, by which many investors subsequently claimed its disadvantages to the ICSID tribunal.12 It was about 47 cases claiming Argentina in the ICSID which considered the first country has received the most cases in the tribunal to date. ${ }^{13}$ This paper, therefore discusses economic development principle for Argentina cases in the ICSID awards which focusing to CMS, Enron, Sempra and LGEE case. This includes the concept of fair and equitable treatment, necessity, self-judging, and responsible investment.

\section{Method}

This article utilized Third World Approach to International Law paradigm to investigate the ICSID awards towards Argentina cases. Thus the notion of debt crisis, first award and appeal awards has been scrutinized for developing a better argument of postcolonial states in the ICSID awards.

\section{Argentina in the ICSID Awards}

The discussion on Argentina and the ICSID award initially concerned to the jurisdiction issues of the tribunal. Then it went further to more conceptual interpretation of what are term investment, diplomatic protection, necessity and compensation pursuant to the Treaty between the United States of America and the Argentine Republic Concerning the Reciprocal Encouragement and Protection of Investment 1991 (BIT) and the customary International Law of International Law Commission's Draft Article on Responsibility of States for Internationally Wrongful Acts 2001 (ILC draft or customary International Law). It can be said that the general discussion on the ICSID awards on Argentina cases are tend to be identical and under comparable circumstances on how to measure the economic crisis and its impacts over the concept of necessity under International Law. However, the awards might consider inconsistent and unsystematic in relation to different interpretations on cases of Argentina. ${ }^{14}$ These emerged both in one case (between original and annulment award) and among one to other cases from the emergence of economic crisis 2001-2002. ${ }^{15}$

11 Argentina's Collapse: A Decline Without Parallel, the Economist, Mar. 2 -8, 2002, at 26, 26. Quoted in William W. Burke White, the Argentine Financial Crisis: State Liability under BITs and the Legitimacy of the ICSID System, Michael Waibel (ed)(2010)The Backlash Against Investment Arbitration, Perceptions and Reality, UK: Kluwer Law International, p. 409.

12 See Bishop R.Doak \& Luzi, Roberto Aguirre 'Investment Claims: First Lessons from Argentina' in Tod Weiler (2005) Op.Cit., , p. 425-469.

13 The listing 47 cases include 22 concluded cases and 25 pending cases. See completely at http://icsid.worldbank.org/ICSID/FrontServlet?requestType=CasesRHEactionVal=ListCases, last updated November 24, 2011, accessed on 26 November 2011.

14 See for example Frank Spoorenberg \& Jorge E.Vinuales, 'Conflicting Decision in International Arbitration', in The Law And Practice Of International Court And Tribunals 8 (2009) the Netherlands: Martinus Nijhoff Publisher, p. 91-113.

15 See in more detail Stephan W. Schill, International Invesment Law and the Host State's Power to Handle Economic Crises, 24 Journal of International Arbitration 265 (2007). 
The ICSID tribunal have provided divergent interpretations of the relationship between the 'essential security' exception contained in Article XI of the BIT and the customary International Law defence of necessity as compiled in article 25 of the ILC draft. The ICSID tribunal on CMS Gas v. Argentina, ${ }^{16}$ Enron v. Argentina,17 and Sempra v. Argentina $^{18}$ initially considered that Argentina had failed to satisfy the conditions for the necessity defence ground, despite the emergency economic crisis in 2001. However, in the annulment award the Ad Hoc committee for Enron and Sempra had annulled the original award based on the misused of interpretation methodology in deciding the case, but still keep the same argument for CMS case that Argentina had contributed to the crisis and disposed of other ways to reach it. ${ }^{19}$

By contrast, it was a breakthrough for the case LGEE Energy Corporation v. Argentina which had exempted Argentina from State responsibility on virtually identical facts for a limited period of time. ${ }^{20}$ This LGEE tribunal supported the necessity defence of Argentina within economic crisis, ${ }^{21}$ and referred its decision on the BIT article XI, which permits a state to take measures necessary for the maintenance of public order and to protect its essential security interest. The tribunal also highlighted that "the exception in the treaty excused Argentina from any obligation to pay compensation during the period of the emergency." 22 This legal reasoning cannot be separated from the judges underlying ideology and methodology by which it contributes to development of International Law of arbitration.

Regarding jurisdiction, The ICSID had confirmed and rejected the argument of the Argentina in several cases $^{23}$ because it was considered unsatisfactory to face the general meaning of investment in the BIT article I (1) (a) stated that:

"Investment" means every kind of investment in the territory of one party owned or controlled directly or indirectly by nationals or companies of the other party, such as equity, debt, and service and investment contract; and includes without limitation:...(ii ) a company or shares of stock or other interest in a company or interest in the assets thereof; 24

16 CMS Gas Transmission Co v the Argentina Republic, ICSID ARB/01/8 (Award) May 12 2005, para. 317, available at http://www.worldbank.org/icsid/cases/CMS_Award.pdf.

17 Enron Corp et al $v$ The Argentina Republic, (ICSID Case no ARB/01/3(Award), 22 May 2007, http://ita.law.uvic.ca/documents/EnronAward.pdf.

18 Sempra Energy Int v Argentina, (ICSID case No. ARB/02/16 (Award) para.346-355, 28 September 2007), http:/ /ita.law.uvic.ca/documents/SempraAward.pdf.

19 CMS Award, paras. $304-394$.

20 LGEE Energy Corp., LGEE Capital Corp., LGEE International Inc. v. The Argentina Republic (ICSID Case No. ARB/02/1(Decision On Liability) October 3, 2006, paras. 201 - 266, available at http://www.worldbank.org/icsid/cases/pdf/09_LGE_Liability_e.pdf.

21 LGEE Decision on Liability, Ibid.

22 Andrea K Bjorklund, ' Emergency Exceptions: State of Necessity and Force Majeure' in Peter Muchlinski et al. (2008) The Oxford Handbook of International Invesment Law, Oxford: Oxford University Press, p. 463.

23 See for example Enron Corp and Ponderosa Assets, L.P. v. Argentina Republic (ICSID case No. ARB/01/3), decision on Jurisdiction (Ancillary Claim) of August 2, 2004, Enron Corp and Ponderosa Assets, L.P. v. Argentina Republic (ICSID case No. ARB/01/3), decision on Jurisdiction of January 14, 2004, CMS Gas Transmission Company v. the Republic of Argentina (ICSID case No.ARB/01/8), decision of the tribunal on objections to Jurisdiction, of July 17, 2003.

24 See completely in article (I) Treaty between United States of America and the Argentine Republic concerning the Reciprocal Encouragement and Protection of Investment 1991. 
The tribunal further examine the claim following the rules on the interpretation of treaties provided in the 1969 Vienna Convention on the law of treaties article 31(1) that:

"[a] treaty shall be interpreted in good faith in accordance with the ordinary meaning to be given to the terms of the treaty in their context and in the light of its object and purpose". Additionally, in article 32 implied to refer the supplementary means of interpretations, including the "preparatory work of the treaty and the circumstances of its conclusion..."

Based on that reference, the tribunal convinced that 'the treaty was made with the specific purpose of guaranteeing the rights of foreign investors and encouraging their participation in the privatization process,...'. ${ }^{25}$ The tribunal further stated that it was not to take any consideration of "measures of general economic policy or to judge whether they are right or wrong", but it would has been focused on "whether specific measures affecting the claimant's investment or measures of general economic policy having a direct bearing on such investment have been adopted in violation of legally binding commitments made to the investor in treaties." 26 Several argument in Argentina cases in ICSID as following:

\subsection{Fair and Equitable Standard}

The investors claimed Argentina for the violation of the 'fair and equitable treatment' standard and 'full protection and security' of the BIT in term of protection of investors and their investments in frame of ICSID convention. ${ }^{27}$ It is held that: "Investment shall at all times be accorded fair and equitable treatment shall enjoy full protection and security and shall in no case be accorded treatment less than that required by International Law". 28 In CMS v Argentina case, as it was confirmed that Argentina had breach this article, consequently it also assessed the compensation on the basis of total loss of the investor's business. This indicated no clear difference between expropriation which should be compensated and the actual breach of BIT which not always need to compensation. The tribunal used the compensation with resorting to the standard of fair market value. ${ }^{29}$

Also, the tribunal considered that Argentina's response to the economic crises was not the only means available to safeguard its interests. This was then one of the grounds on which the tribunal rejected Argentina's argument. ${ }^{30}$ Furthermore, in LG\&E case the tribunal affirmed that the "fair and equitable standard consists of the host State's consistent and transparent behavior, free of ambiguity that involves the obligation to grant and maintain a stable and predictable legal framework necessary to fulfill the justified expectations of the foreign investor. 31 However there is no common

25 See Enron Corp and Ponderosa Assets, L.P. v. Argentina Republic (ICSID case No. ARB/01/3), decision on Jurisdiction (Ancillary Claim) of August 2, 2004, para. 32.

26 See Enron Ancillary Claim, Ibid., para. 12; see also CMS Gas Transmission Company v. Argentina Republic (ICSID Case No. ARB/01/8), decision on jurisdiction of July 17, 2003, par.33.

27 Ian Laird 'the emergency exception and the state of necessity' in Federico Ortino et al. (2007) Investment Treaty Law, Current Issues II, Nationality and Investment Treaty Claims, Fair and Equitable Treatment In Investment Treaty Law, London: British Institute of International and comparative Law, p. 237-251.

28 Article II.2 (a) of the US-Argentina Bilateral Investment Treaties 1991.

29 Weiniger, Matthew, "the standard of compensation for violation of the fair and equitable treatment standard" in Federico Ortino et al. (2007) Investment Treaty Law, Current Issues II, Nationality And Investment Treaty Claims, Fair And Equitable Treatment In Investment Treaty Law, London: British Institute of International and comparative Law, p.202.

30 CMS Award at paras. 323-324.

31 See also LGEE decision: "[...] Having created specific expectations among investors, Argentina was bound by its obligations concerning the investment guarantees vis-à-vis public utility licensees, and in 
understanding on how to measure fair and equitable standard for host states in International Law.

\subsection{Necessity}

The discussion on State of necessity as a defence for Argentina in responding the claim from the United States of America (USA's) investors in the ICSID has been explicitly showed the continual paradox within the international investment system which is referred to both treaties and international customary law. Although it is considered the first case on the necessity defence argument in economic crisis circumstances that attracted widely attention in the tribunal argument but it would not solve the main problem of what Bilateral Investment Treaties (BIT) for. ${ }^{32}$

According to the concept of the plea of necessity which has been deliberately discussed in International Law Commission (ILC), the term necessity includes the defence, force majeure and distress. It was understood as contemporary in nature, that is to say that once a state of necessity ends, the obligation to comply with the treaty should resume. According to the ILC, necessity is not a question of jurisprudence or admissibility, it is distinct from the obligation themselves, like fair and equitable treatment. It is also important to remember that it may not be invoked unless strict conditions are met. ${ }^{33}$ Article 25 of the ILC draft article on state responsibility provides that:

(1) Necessity may not be invoked by a state as a ground for precluding the wrongfulness of an act not in conformity with an international obligation of that stats unless the act:

(a) Is the only way for the state to safeguard an essential interest against a grave and imminent peril; and

(b) Does not seriously impair an essential interest of the state or states toward which the obligation exists, or of the international community as a whole.

(2) In any case, necessity may not be invoked by a state as a ground for precluding wrongfulness if:

(a) The international obligation in question excludes the possibility of invoking necessity; or

(b) The state has contributed to the situation of necessity. ${ }^{34}$

The first commentary of the article mentioned that the term "necessity" (état de nécessitê) is used to denote those exceptional cases where the only way a state can safeguard an essential interest threatened by a grave and imminent peril is, for the time being, not to perform some other international obligation of lesser weight or urgency. Under conditions narrowly defined in article 25 , such a plea is recognized as a circumstance

particular, the gas distribution licensees. The abrogation of these specific guarantees violates the stability and predictability underlying the standard of fair and equitable treatment" in LGEE Energy Corp., LGEE Capital Corp. and LGEE International Inc. v. Argentine Republic, ICSID Case No. ARB/02/1, Decision of the Arbitral Tribunal on Objections to Jurisdiction, 30 April 2004, Decision on Liability, 3 October 2006, para. 133.

32 Burke-White, William W., "The Argentine Financial Crisis: State Liability Under BITs and the Legitimacy of the ICSID System" (2008) Scholarship at Penn Law. 202. http://lsr.nellco.org/upenn_wps/202, accessed on 16 November 2011.

33 See a complete analysis in August Reinisch, Necessity in Investment Arbitration in I.F. Dekker and E.Hey (eds.) Netherlands Year Book of International Law Vol. 41, 2010, The Hague, T.M.C. Asser Institute, p. 137-157.

34 International Law Commission, Report of the International Law Commission: Draft Articles on the Responsibility of States for Internationally Wrongful Acts, U.N. Doc. A/56/10 (2001). 
precluding wrongfulness." 35 The necessity argument application under International Law from Argentina case has posed a question on International Law concern toward the relation between state and state or between state and investor. The question is remained unresolved in what circumstances the situation of economic crisis can be qualified under the concept of necessity of international customary law and state v. investor can be competed to. However, the concept also consider the general rule of law which gave an exception to a state to provide a precedence to certain duties to its people over the repayment of debt obligation even this governed by the private law. Based on state practices and the precedent of international courts, it can be concluded that economic necessity has always been recognized as a general principle that permitted a state to suspend its payment obligations vis-à-vis private individuals. Particularly it can be emphasized that the state practices documented by the ILC during its work on the Draft Articles suggested that necessity has been available as a matter of principle, independent of the legal source of the claims asserted against a state. ${ }^{36}$

It is an idea that the country was in a state of necessity at least for a certain period for which reason it should be (at least partially) exempted from responsibility. The LG\&E Tribunal, for example, held that the evidence put before it showed that from December 1, 2001 until April 26, 2003 when Argentina was in a period of crisis "during which it was necessary to enact measures to maintain public order and protect its essential security interest." 37 The Tribunal concluded that during this period the protections afforded by Article XI of the BIT were triggered to maintain order and control civil unrest.

Regarding the other allegations raised by the Claimants, the Tribunal, following CMS v. Argentina, rejected the argument that Argentina's measures amounted to an expropriation in breach of the BIT. In doing so, the tribunal considered the economic impact of the measures, the degree of interference with Claimants' use and enjoyment of their investment and the duration of the measures. The Tribunal found, however, that Argentina breached its obligations to accord Claimants a fair and equitable treatment and its obligations under the umbrella clause. The Tribunal also concluded that while Argentina's measures may not have been arbitrary, they were discriminatory in nature and thus, in breach of the BIT. 38

It is also a worried that the necessity defence will be used easily by the state in justifying their decision as in CMS case described:

If strict and demanding conditions are not required or are loosed applied, any state could invoke necessity to elude its international obligations. This would certainly be contrary to the stability and predictability of the laws. ${ }^{39}$

In one side the state has an obligation to apply the treaty and in another side the state also has an exception to violate the treaty as necessity based. It is an opponent to question the validity of necessity under International Law particularly referring to the

35 Responsibility of States for Internationally Wrongful Acts, General commentary, accessed on 12 November 2011 at http://untreaty.un.org/ilc/texts/instruments/english/commentaries/9_6_2001.pdf. p. 80-81.

36 Ibid.

37 See LG EE Energy Corp., LGEE Capital Corp., LGEE International, Inc v Argentine Republic (ICSID Case No.ARB/02/1, Award) July 25, 2007, para.2-3.

38 Claudia Frutos-Peterson, LGEE Energy Corp., LGEE Capital Corp. and LGEE International Inc. $v$. Argentina Republic (ICSID Case No. ARB/02/1), introductory note, ICSID Review, Foreign Invesment Law Journal, p. 150-154

39 CMS Award at para 317. 
ILC draft on state responsibility. They argued that there were no consistently states practice and opinio jurists to support such argument. the application of necessity in investor-state arbitration as a counterargument against the majority's position that necessity was inapplicable in the relationship between a State and an individual and pointed out that diplomatic protection cases essentially presented causes of action that were fundamentally identical with the underlying private law claims.

The term 'necessity' has been mentioned in the article XI of the BIT as 'essential security" and explicitly in article 25 of ILC draft article. Essentially, Argentina did not specifically apply its economic emergency policy to the investors as a discriminations act; it was unintentionally act due to economic necessity of people during the hit of economic crises. Thus, there have been some circumstances to exempt from the wrongfulness as recognised by the ILC draft article include consent by another state to the violation of an obligation toward that state, self-defence, countermeasures taken in respect of an internationally wrongful act, force majeure, distress, and necessity. ${ }^{40}$ Accordingly, the necessity doctrine and force majeure become the most likely line of defence in investment. Particularly in Argentina case, the necessity doctrine become prominently refers to the economic crisis in Argentina. Bjorklund explained the different of two as following:

As state may invoke the necessity doctrine as a ground for precluding wrongfulness if violating the obligation is the only way for the state to safeguard an essential interest against a grave and imminent peril. In contrast, force majeure may be invoked in the event of unforeseen event outside the control of a state which make it materially impossible for the state to abide by its obligation... force majeure precludes wrongfulness when the violation is due to an irresistible force or unforeseen event that is beyond the control of the state, whereas necessity precludes wrongfulness when a state acts voluntarily in violating its obligation, but in manner necessary to protect an essential interests in grave and imminent peril. ${ }^{41}$

In the BIT the term 'essential interests' used without definition, in which the tribunal refers this term to the scope of 'grave and imminent perils'. The tribunal accepted that economic interests could fall under that essential interest. 42 Factually, the tribunal in CMS case set out a strict assessment concerning in what circumstances the essential interest and necessity can be exercised in economic crises, which are there must be a total economic and social collapse. ${ }^{43}$ Hence, the tribunal concluded that the fact in Argentina was not met the criteria for the plea of necessity. The vague of this term seems need to be examined base on real situation. Equally, the sub 2 of article 25 ILC draft on state responsibility mentioned that in any case necessity may not be invoked by a state as a ground for precluding wrongfulness if, and there are a couple of conditions: “(a) The international obligation in question excludes the possibility of invoking

40 Crawford, J (2002) The International Law Commission's Article on State Responsibility: Introduction, Text And Comentaries, Cambridge : Cambridge University Press, article 20-25, p.160-186.

41 Andrea K Bjorklund, 'Emergency Exceptions: State of Necessity and Force Majeure' in Peter Muchlinski et al. (2008) The Oxford Handbook of International Invesment Law, Oxford: Oxford University Press, p. 461-462.

42 CMS Award at para 319: again here the issue is to determine the gravity of the crisis. The need to prevent a major breakdown, with all its social and political implications, might have entailed an essential interests of the state in which cases the operation of the states of necessity might have been triggered.

43 CMS Award at para 355. 
necessity, or (b) The state has contributed to the situation of necessity". ${ }^{44}$ This clause was the basis for a major argument by the claimant in the case which was accepted by the tribunal. Furthermore, if we look at the BIT, there are might be two related provision on this case. Firstly, article IV(3) stated that:

Nationals or companies of either party whose investments suffer losses in the territory of the other party owing to war or other armed conflict, revolution, state of national emergency, insurrection, civil disturbance or other similar events shall be accorded treatment by such other party no less favourable than that accorded to its own nationals or companies or to nationals or companies of any third country, whichever is the more favourable treatment, as regards any measures it adopts in relation to such loses. ${ }^{45}$

Secondly, article XI which is more related to the issues concerned. It is said:

This treaty shall not preclude the application by either party of measures necessary for the maintenance of public order, the fulfilment of its obligations with respect to the maintenance or restoration of international peace or security, or the protection of its own essential security interests. 46

In its interpretation, the CMS tribunal regard that no such national case treatment breached in this context as stated in article IV(3). However, regarding the article XI, it is worth to question what is an 'essential security interests' mean in understanding the tribunal conclusion that the crisis in Argentina itself not sufficiently meet the standard.47 CMS tribunal also states that 'fair and equitable treatment is inseparable from stability and predictability' ${ }^{48}$ The tribunal indicated that there must be a total economic and social collapse. So even though there is an extremely serious economic crisis occurred in Argentina, the respondent was not permitted to rely on the plea of the necessity to avoid its obligation to meet the fair and equitable standard in the BIT. Hence, the meaning of national security and state of necessity is not defined in International Law yet. Therefore, this uncertain meaning has given to the tribunal to judge based on his interpretation. The CMS tribunal seems very strict on defining the criteria which exclude the Argentina's economic situation from emergency or state necessity.

The argument whether the necessity can be justified for Argentina behaviours in responding economic crisis should also be seen from the background of the crisis that is the failure of the IMF to refund the loan due to its strict conditionality failure. The colonial nature of international Investment Law system has been perceived since the colonial and postcolonial period in international foreign investment arrangements.

\subsection{Rebus sic stantibus}

Comparatively, the Argentina case could also showed the principle 'rebus sic stantibus' or hardship situation that made Argentina very difficult to continue the existing

44 International Law Commission, Report of the International Law Commission: Draft Articles on the Responsibility of States for Internationally Wrongful Acts, U.N. Doc. A/56/10 (2001).

45 Treaty between United States of America and the Argentine Republic Concerning the Reciprocal Encouragement and Protection of Investment 1991, Article IV (3).

46 Ibid., Article XI.

47 CMS Award at para 359-61.

48 CMS Award at para 276. 
contracts. ${ }^{49}$ This doctrine can be regarded as a lay out after 'force majeure' doctrine in terms of degree of hardship. 50 This principle further recognised in UNIDROIT principle as an exception to Pacta sun Servanda principle and this also adopted in the Vienna Convention on the Law of Treaties 1969 article 61 (1) on Supervening impossibility of performance that comprises of hardship condition in contracts and basic situational changes in contract implementing, as follows:

A party may invoke the impossibility of performing a treaty as a ground for terminating or withdrawing from it if the impossibility results from the permanent disappearance or destruction of an object indispensable for the execution of the treaty. If the impossibility is temporary, it may be invoked only as a ground for suspending the operation of the treaty.

Equally, the UNIDROIT Principles (Principles of International Commercial Contracts 1994) as a reference in drafting international contract has adopted rebus sic stantibus in section 2 under the title of Hardship. Hardship is a situation when contract equilibrium fundamentally changes due to the cost of implementing increases significantly from the contract. The criteria of hardship according to UNIDROIT Principles 2010 article 6.2.2 are as following:

There is hardship where the occurrence of events fundamentally alters the equilibrium of the contract either because the cost of a party's performance has increased or because the value of the performance a party receives has diminished, and (a) the events occur or become known to the disadvantaged party after the conclusion of the contract; $(b)$ the events could not reasonably have been taken into account by the disadvantaged party at the time of the conclusion of the contract; (c) the events are beyond the control of the disadvantaged party; and(d) the risk of the events was not assumed by the disadvantaged party.51

If the hardship emerges, there might be some possibilities to the parties as mentioned in article 6.2.3. on the effect of hardship:

(1) In case of hardship the disadvantaged party is entitled to request renegotiations. The request shall be made without undue delay and shall indicate the grounds on which it is based. (2) The request for renegotiation does not in itself entitle the disadvantaged party to withhold performance. (3) Upon failure to reach agreement within a reasonable time either party may resort to the court. (4) If the court finds hardship it may, if reasonable, (a) terminate the contract at a date and on terms to be fixed, or (b) adapt the contract with a view to restoring its equilibrium. 52

The ICSID has indicated to the crisis of a clear methodology of their decision. ${ }^{53}$ The conflicting decision in Argentina case in the ICSID tribunals has basically focused on the content of the Bilateral Investment Treaty (BIT) and the International Law Commission Draft of Customary International Law 2001 (the ILC draft). The BIT has

49 Giorgio Gogiashvili, "Clausula rebus sic stantibus : Dynamics and Statics in Law”, Georgian Law Review 9/2006 - 1/2, hal.109.

50 Aziz T. Saliba, Rebus Sic Stantibus: A Comparative Survey, E-Law Murdoch University Electronic Journal of Law, Vol. 8, No. 3, September 2001, hal.3.

51 UNIDROIT principle of international commercial contract 2010. Available online at: http://www.unidroit.org/english/principles/contracts/principles2010/blackletter2010-english.pdf, assessed in 15 November 2010.

52 Ibid.

53 In regard of the inconsistency of investment arbitration and its reasoning, see Susan D. Franck, (2005) 'The Legitimacy Crisis in Investment Treaty Arbitration: Privatizing Public International Law Through Inconsistent Decisions', Fordham Law Review, Vol . 73, issue 4, p. 1546 
been obviously focusing to the economic development, without directly benefit the people in host states.

\section{Annulment Awards: A Fragmented Methodology}

The Annulment Award of Argentina case in which criticized the original arguments has posed a question on the methodology and legal reasoning of the tribunal. The concern was focused on the uncertainty of concept of necessity in the ILC draft of international customary international law and the essential interest of the BIT in general. Such decision can be seen from On 29 June 2010 the ad hoc ICSID committee annulled the initial award of Sempra International Energy v. Argentina, Enron Corperation $\mathcal{E}$ Ponderosa Asset $v$. Argentina and Vivendi v. Argentina. ${ }^{54}$ There was a serious departure from a fundamental rule of procedure 55

In Sempra, the committee had annulled the ordinary award due to the complete "failure to apply the applicable law". According to the committee the ICSID tribunal had seen the article XI of the BIT as being "inseparable from customary law standard insofar as the definition of necessity and the conditions for its operation are concerned". The committee insisted that both sources should be stand alone criteria, and the BIT should be the main sources of this argument. On the original award, the tribunal seemed to proceed on basis that two regimes were equivalent when it said there was no need to "undertake a further judicial review under article XI given that the article does not set out conditions different from customary International Law in this regard". Sahib Singh commented on Sempra Annulment decision that the ad hoc annulment committee has revised the initial award on Sempra case, finding that the initial tribunal had exercised a manifest excess of powers in respect of its failure to apply Article XI of the BIT as follow:

For reasons which will be discussed in greater detail later, the Committee finds that the Award must be annulled in its entirety on the basis of manifest excess of powers (Article 52(1)(b) of the ICSID Convention) in respect of failure to apply Article XI of the BIT. The question therefore arises whether it is necessary for the Committee to deal with other arguments advanced by Argentina in relation to the way in which the Tribunal dealt with Article XI. The Committee feels that it should deal with these arguments for the sake of completeness. 56

The concern is the methodology of interpretation of 'necessity was considered inconsistent and quite obscure. That is to say that the initial tribunal has misunderstanding the 'necessity' in article XI BIT and customary International Law. ${ }^{57}$

54 In the ICSID convention article 52 stated that an award may be annulled only on one or more of the following grounds: The tribunal was not properly constituted, The tribunal manifestly exceeded its power, There was corruption on the part of a member of a tribunal, There was a serious departure from a fundamental rule of procedure, The award does not state the reasons on which it is based.

55 See Matthias Scherer, ICSID Annulment Proceedings Based on Serious Departure from a fundamental Rule of Procedure, in Czech E Central European Yearbook of Arbitration, p. 211-226.

56 See complete arguments at Sempra Energy International v. Argentina Republic (ICSID Case No. ARB/02/16) (Annulment Proceeding) on 29 June 2010, para. 160-165.

57 Sahib Singh, Necessity in Investor-State Arbitration: The Sempra Annulment Decision, 16 August 2010, http://www.ejiltalk.org/necessity-in-investor-state-arbitration-the-sempra-annulment-decision, accessed on 15 November 2011. 
The notable argument of the annulment committee of Sempra case is quoted as below:

This sequence of argument is illogical as the question whether a state of necessity justifies exoneration from state responsibility will become an issue only where liability is not already precluded under Article XI of the BIT. As a general rule, a treaty will take precedence over customary International Law. 58

In order to interpretation of International Law treaties, according to article 31(1), the first point for interpretation of a BIT is the 'ordinary meaning' of the words of the treaty themselves. The committee concluded that "...that it may be appropriate to look to customary law as a guide to the interpretation of terms used in the BIT". 59 The concern in the Sempra annulment award is the correction on the hierarchy of norm in term of whether the primary and secondary rules can be referred in interpreting necessity in Argentine case. In this regard Article XI of BIT should be the Primary Source of the necessity defense, and the decisive and operative rule. The Sempra committee's attempt to define its scope and application on where the decision really comes into its own, departing significantly from previous decisions. The committee notes that "Articles 25 of the ILC draft does not offer a guide to interpretation of the terms used in Article XI." This statement departs from tribunal's approach in Continental Casualty which noted that it will "focus on the analysis of Art. XI and the conditions of its application, referring to the customary rule on State of Necessity (as enshrined in Art. 25 of the ILC draft) only insofar as the concept there used assist in the interpretation of Art. XI itself". ${ }^{60}$ The Sempra committee reasons that customary definition can offer no guidance to interpretation due to: (a) the terms of each rule, Articles XI and 25, significantly differ; and (b) they operate on different hierarchy: primary and secondary, "therefore deal with quite different situations". ${ }^{61}$

Differently in Enron, it stated that the tribunal was entitled to equate article XI of the BIT and customary International Law. However, it considered that the tribunal had failed to apply a number of the essential legal element of the 'necessity' defence under customary International Law. For example that the committee did not assess that the Argentina emergency policy is 'the only way' to safeguard an essential security interest. They just relied on the opinion of an economic expert who said that Argentina had multiple policy options in dealing with the crisis. The failure to comprehend the legal qualification of necessity in the ILC draft meant that it had neglected to apply the applicable law and thereby manifestly exceeded its power. ${ }^{62}$

Hence, the different decision on the Annulment committee of the Enron case has referred to the interpretation of the tribunal on the 'only way' under 'necessity' doctrine in the customary International Law. The committee described as follows: The tribunal was required to determine whether, on the proper construction of Article 25(1)(a) of the ILC Articles, the "only way" requirement in that provision was satisfied, and not merely whether, from an economic perspective, there were other options available for dealing with the economic crisis. The Committee concludes that in determining that the measures adopted were not the "only way", the Tribunal did not in fact apply Article 25(1)(a) of the ILC Articles (or more precisely, customary International Law as

58 Sempra Annulment Proceeding, para. 176.

59 Sempra Annulment Proceeding, para. 197.

60 Continental Casualty Company v. Argentine Republic (ICSID Case No. ARB/03/9) (Award) 5 September 2008, para. 168.

61 See Sempra Annulment Proceeding, para 199-200.

62 See the ICSID Convention article 52 (b). 
reflected in that provision), but instead applied an expert opinion on an economic issue. In all the circumstances the Committee finds that this amounts to a failure to apply the applicable law, as ground of annulment under Article 52(1)(b) of the ICSID Convention. ${ }^{3}$ This decision has supported the Argentina standing for people necessity in economic crisis and accordingly precluded from the obligation under the treaty as well as the compensation as it was mentioned in the Enron original award. The annulment committee criticized the failure of sufficiently interpret the term 'only way' under article 25 (a) of the ILC draft Articles as follows: "(1) Necessity may not be invoked by a State as a ground for precluding the wrongfulness of an act not in conformity with an international obligation of that State unless the act: (a) is the only way for the State to safeguard an essential interest against a grave and imminent peril.64

There has been undetermined on how to measure the 'only way' to be qualified of precluding the wrongful act in term of necessity doctrine. Whether the 'only way' negate other possible alternatives, or how to priorities one alternative from others were become further analyses. Sahib Singh criticized the annulment committee in interpretation the term 'only way' as an uncertainty concept which creates more convoluted issues. However, he cannot clearly explains the best way to dealt with such situation. He just opens the complexity of understanding of the concept necessity as the annulment committee provided which can be measured through the 'gravity of breach' or the degree of 'effectiveness' of such measures. 65 The further incisive question was emerged by the tribunal is 'whether the necessity defense is precluded if the State pursues a measure which is more effective but illegal, when it possesses the capability to pursue a measure which is legal but far less effective' ${ }^{6} 6$

It seems that the ICSID decision on Argentina cases in several claims of investors had indicated that the people necessity being contended with the investors interests. In LGEE tribunal on 2006 decision on liability, ${ }^{67}$ it was argued that the ICSID tribunal has ignored the earlier decision and findings of the CMS $v$. Argentina case (2005). ${ }^{68}$ This case explained that the situation in Argentina during a 15 months period between 2001 and 2003 constitutes a state of necessity, which exempted the Argentina as a responding state of its liability for violating various investment standards under the Argentina-US BIT.69 However, in CMS case, the tribunal also applied the customary International Law of necessity and concluded that the Argentina actions were not excused by the necessity defence. The annulment committee refuse to annul the CMS award, saying that the tribunal had not manifestly exceeded its powers, even there might have been a defective application of the law, but the tribunal was not guilty of failing to apply the

63 See Enron Creditors Recovery Corp. Ponderosa Assets, L.P. v. The Argentina Republic (ICSID Case No. ARB/01/3) (Annulment Proceeding) 30 July 2010, para. 377. Accessed on 15 November 2011 from http:/ / italaw.com/documents/EnronAnnulmentDecision.pdf.

64 Responsibility of States for Internationally Wrongful Acts, General commentary, accessed on 12 November 2011 at http://untreaty.un.org/ilc/texts/instruments/english/commentaries/9_6_2001.pdf.p.80.

65 See Sahib Singh, The Enron Annulment Decision's exposure of Necessity's Endemic Uncertainty: A Welcome Critique , 25 October 2010, in http://www.ejiltalk.org/the-enron-annulment-decision $\%$ E2\% 80\%99s-exposureof-necessity \% E2\% 80\%99s-endemic-uncertainty-a-welcome-critique/\#more-2732, accessed on 15 November 2011.

66 See Sahib Singh, Ibid.

67 LGEE Energy Corp., LGEE Capital Corp., LGEE International Inc. v. The Argentina Republic, ICSID Case No. ARB/02/1, Decision on Liability, 3 October 2006, 46 International Legal Materials 40 (2007).

68 CMS Award

69 See LG EE Energy Corp., LGEE Capital Corp., LGEE International, Inc v Argentine Republic (ICSID Case No.ARB/02/1, Award) July 25, 2007, para.2-3. 
law. ${ }^{70}$ This different conclusion remains debated in International Law view as the inconsistency of interpretation and application of 'necessity' concept in international arbitration law.

Concerning the CMS annulment award on September 25, 2007, it was initially the Argentina has submitted an objection of the CMS award, and proposes for annulment decision in the ICSID. Argentina first submits that the Tribunal "manifestly exceeded its powers by exercising jurisdiction over claims by a company's shareholder for income lost by the company." It also contends that it did so "by authorizing CMS, which was not a party to any of the applicable instruments, to claim a breach of obligations" under Article II(2)(c) of the treaty, the so-called "umbrella clause". Also Argentina submits that the Tribunal in its decision on jurisdiction and in its finding relating to the BIT and customary International Law of necessity as well as in its calculation of damages, failed to state the reasons on which the award is based, contrary to Article 52 (e) of the ICSID Convention. Article II(2)(a) of the BIT provides: "Investment shall at all times be accorded fair and equitable treatment, shall enjoy full protection and security and shall in no case be accorded treatment less than that required by International Law." It then reply that "...the Tribunal correctly rejected Argentina's defense on necessity under customary International Law in stating that Argentina's measures were not the only steps available to it and that Argentina contributed to the crisis". ${ }^{71}$ The argument of the tribunal is based on interpretation of "Not only way", temporary concession (article 27 ILC draft) as following:

The invocation of a circumstance precluding wrongfulness in accordance with this chapter is without prejudice to: (a) compliance with the obligation in question, if and to the extent that the circumstance precluding wrongfulness no longer exists; the question of compensation for any material loss caused by the act in question.

Therefore, in the CMS annulment award, even though the committee admitted the shortcoming of precious award, but eventually it was not annulled, as follow:

Throughout its consideration of the Award, the Committee has identified a series of errors and defects. The Award contained manifest errors of law. It suffered from lacunae and elisions. All this has been identified and underlined by the Committee. However the Committee is conscious that it exercises its jurisdiction under a narrow and limited mandate conferred by Article 52 of the ICSID Convention. The scope of this mandate allows annulment as an option only when certain specific conditions exist. As stated already (paragraph 136 above), in these circumstances the Committee cannot simply substitute its own view of the law and its own appreciation of the facts for those of the Tribunal. ${ }^{72}$

Based on ICSID reasoning above, according to Vienna Convention on the Law of Treaties 1969 (VCLT) it can be seen that the tribunal was very strictly used 'the terms of treaty in their context...", that is the BIT and customary International Law as the reference. However, the article 31 of Vienna convention has placed quite comprehensive methodology of reasoning as following:

70 See CMS Gas Transmission Company v the Argentina republic, (ICSID case No. ARB /01/8) (Annulment Proceeding), 25 September 2007 on Decision of the Ad Hoc Committee on the application for Annulment of the Argentina Republic. Para.158.

71 See CMS Annulment Proceeding, para.117.

72 See CMS Annulment Proceeding, para. 158. 
(1) A treaty shall be interpreted in good faith in accordance with the ordinary meaning to be given to the terms of the treaty in their context and in the light of its object and purpose.

(3) there shall be taken into account, together with the context: (c) any relevant rules of International Law applicable in the relations between the parties. ${ }^{73}$

Even more, the article 31 para. 3 (c) has opened a space for the tribunal to utilize other sources in International Law in order to cover all related rules to interpret the 'necessity' in the context of Argentina. This rules can be referred to article 38 (1) of the International Court of Justice Statute 1945 which includes international conventions, international customary law, general principle of law, and judicial decision as jurisprudence. ${ }^{74}$ In this sense, the ESD of people in international human rights convention should be adopted in order to strengthen the meaning of necessity from purposive term of interpretation. This method might contribute to counter the fragmentation and inconsistency of the judicial decisions to some degree. ${ }^{75}$ Even more, if the tribunal consider ESD as a peremptory norm of general International Law, the discussion on the Argentine award would be different, as it stated in article 64 of the VCLT that "if a new peremptory norm of general International Law emerges, any existing treaty which is in conflict with that norm becomes void and terminates".

Hence, the Argentine case can open to a new turning point to current International Law, in particular international Investment Law, that is to say the objective of International Law is not merely to 'maintain peace and security'76 within world war paradigm, but more to ensure the necessity of people in the current world order. So both investors, states of origin and host states should have equal responsibility in preventing, promoting and recovering economic necessity which most likely negatively impact to quality of people's life. Additionally, it has been implicit role of IMF conditionality in responding the economic crisis in Argentina. In this regard, the tribunal should also consider the causal-effect relationship of economic crisis to share the same burden of this disadvantage to all involving stakeholders. It can be said that it is not fair place all the burden of economic crisis merely over the state, where there has been several stakeholders involved.

However, there are some limitations, that necessity may only be invoked to safeguard an essential interest from a grave and imminent peril. The ILC Committee of experts on State Responsibility through its Chairman Roberto Ago, stated in 1980 that the "essential state interest" that would allow the state to breach its obligation must be a vital interest, such as "political or economic survival, the continued functioning of its essential services, the maintenance of internal peace, the survival of a sector of its population, the preservation of the environment of its territory or a part thereof, etc." 77

73 See the Vienna Convention on the Law of Treaties 1969, article 31 (1) and (3) (c).

74 According to article 38(1) of Statute of International Court of Justice, the sources of International Law are International conventions, international customs, general principle of law, judicial decision and the teachings of the most highly qualified publicists of the various nations.

75 See a more complete analises in Vassilis P. Tzevelekos, The Use of Article 31(3)(c) of the VCLT in The Case Law of the ECTHR: an Effective Anti-Fragmentation Tool or a Selective Loophole for the Reinforcement of Human Rights Teleology? Between Evolution and Systemic Integration, Michigan Journal of International Law, Vol. 31, Spring 2010, pp. 622-685.

76 See the preamble of the United Nation Charter 1945.

77 Documents of the Thirty-Second Session (1980), 2 Y.B. Int'1 L. Comm'n 14, U.N. Doc. A/CN.4/SER.A/ 1980/Add.1 (Part 1). 
Furthermore, the report by Crawford, noted that "essential" cannot be defined and must depend on the specific facts of each case. ${ }^{78}$

The different nature of the BIT with other diplomatic protection which the investors were subject to whatever political or legal determination the state of nationality would make in respect of its claim. This new development has given more protection to the investor independently from its nationality identity. Also it gave an investor its legal personality to claim host states where they were operating. In this regard Argentina faced the investor as equal subject before the tribunal. However this was not really explored in what means the state as a primary legal subject in International Law and its investment policies has excluded from the consideration of the tribunal. In other words the investor has replaced the role of states in investment tribunal. ${ }^{79}$ In traditional sense, the investor should claim to the company of Argentina before the court in Argentina as it has shareholder in the Argentina Company, or the US on behalf of its investor's claims Argentina before the ICSID regarding the violation of the treaty between the US and Argentina. This had highlighted by the Argentina argument that "shareholders cannot claim separately from corporation, not even in proportion to their interest, as they would have only an indirect claim. Argentina argues, corporate personality does not allow for indirect claims by shareholders." 80

In relation to the protection of alien property as the responsibility of host states doctrine in International Law, Sornarajah aptly described that " the old rules were made in the context of the taking of real property and physical assets of the foreigners. The modern takings are largely by way of breach of contractual agreements and by the withdrawal of permission to do business. The old law has little to do with takings of property in pursuance of economic programme." 81

The legal approaches have asserted two broad arguments which raise deeper structural questions about the rights of states to respond to extraordinary situations such as a massive financial crisis. Specifically, Argentina has invoked the Non Preclude Measure (NPM) clauses of its BIT and has asserted that the state of necessity in customary International Law precludes the wrongfulness of its actions. It allows states to take actions otherwise inconsistent with the treaty when, for example, the actions are necessary for the protection of essential security, the maintenance of public order, or to respond to a public health emergency. The NPM provisions effectively "permit host state impairment of covered investment" and, in turn, weaken the BIT "as an instrument for regulating host-state governments." 82 In each of the cases arising under the U.S.-Argentina BIT, Argentina has argued that its actions in response to the financial crisis of 2001-2002 were justified as measures necessary to protect essential security and public order and that, because those actions fell within the provisions of the NPM clause. They did not violate the substantive protections accorded investors

78 Second Report on State Responsibility: Addendum, Int'1 L. Comm'n, 51st Session, at 30, U.N. Doc. A/CN.4/498/Add.2 (1999).

79 See Enron Corp and Ponderosa Assets, L.P. v. Argentina Republic (ICSID case No. ARB/01/3), decision on Jurisdiction (Ancillary Claim) of August 2, 2004, para. 37.

80 See Enron Ancillary Claim, para. 17.

81 See Sornarajah, M (2004), Op.Cit, p. 157.

82 See the explanation of NPM clause in Burke-White, William W., "The Argentine Financial Crisis: State Liability Under BITs and the Legitimacy of the ICSID System" (2008). Scholarship at Penn Law. Paper 202.http://lsr.nellco.org/upenn_wps/202. 
under the BIT. Thereby there was no internationally wrongful acts were committed and no state liability should attach. ${ }^{83}$

This considers the justification advanced by the tribunal for accepting most of investor's claims without taking into account the purposive of the BIT for economic development. It finds the turn to Investment Law for purposes of interpreting the 'essential security' clause to be deeply flawed for contextual and systemic reasons. It should be noted that most of investors as representing the economic colonial power ${ }^{84}$ to take into account the community development through the state. However, investment has become trapped to dependency theory which the host states become continual dependence to the foreign investors in years post decolonisation. 85 The investor has a special arrangement with the elite government to share the benefit with mostly marginalising people interest in general.86 Furthermore, there are three essential modes of protection foreign investment. Firstly is related to the rules of states responsibility for injuries to alien. Secondly, the WTO law has partly regulated some protection of foreign investment through Trade Related to Investment Measures (TRIMS). Thirdly, the doctrine of international treaty both bilateral and multilateral can override the economic sovereignty of host states. ${ }^{87}$ These protections are represented the classical theory of economic liberalism with prefer to protect investors than people in a states. ${ }^{88}$ The essential idea is that the economic development of host states should be paramount to other interests in economic crisis context. Argentina has explicitly followed this idea during the economic crisis since 2001. However its policy has been claimed as an offence under BIT and customary International Law by investors.

The absence of code of conduct for inventors during economic crises in host states was a defect of current international Investment Law. It should be noted that the sense of economic crises is not only the burden of a host states, but also the foreign investors as the emerging of responsible investor's standard in international law. ${ }^{89}$

\section{The ICSID Arbitration Awards: The Crisis of Consistency}

The inconsistent of investment arbitration decision as described by Franck has opened a chance to place a more similar reference for this arbitration. The reasons of different treaties have different contents which affected to different reasoning of arbitrations has been a problem for the future of investment arbitrations. So utilising legal principle beyond the existing treaties would help to some extent to focus the destiny of the

83 See Kenneth J. Vandevelde, of Politics and Markets: The Shifting Ideology of the BITs, 11 INT'L TAX \& BUS. LAW. 159, 170 (1993).

84 See the colonial history nature of international Investment Law in Francesco Francioni, access to justice, denial of Justice and international Investment Law, The European Journal of International Law (2009) Vol.20 no.3, 2009, 729- 747, http:/ / ejil.oxfordjournals.org/ accessed on November 7, 2011.

85 See further explanation in MYA. Kadir, Application of the Law of Self-Determination in a Postcolonial Context: A Guideline, Journal of East Asia and International Law 9 (1), 7, and MYA Kadir and A. Murray, "Resource Nationalism in the Law and Policies of Indonesia: A Contest of State, Foreign Investors, and Indigenous Peoples", Asian Journal of International Law, (2019) 1-36.

86 See also the proportional approaches proposal in Sweet, Alec Stone, "Investor-State Arbitration: Proportionality's New Frontier" (2010). Faculty Scholarship Series. Paper 69. Source: http://digitalcommons.law.yale.edu/fss_papers/69, assessed on 15 November 2011.

87 See Sornarajah, M (2004) The International Law on Foreign Investment, Cambridge: Cambridge University Press, p. 104-105.

88 See similar critique in Sarah Anderson and Sara Grusky, Op.Cit.

89 See some proposed responsibility both for state and investor in principle of human rights and transnational corporation, 21 March 2011, accessed on 16 November 2011 at http://www.businesshumanrights.org/media/documents/ruggie/ruggie-guiding-principles-21-mar-2011.pdf. 
arbitration. In this sense purposive approaches could be an alternative to settle the investment disputes. Franck argues that 'under the current framework, the options for addressing these inconsistent decisions are limited. ${ }^{90}$ There is no coherent system for addressing inconsistencies across the investment treaty network and, as demonstrated by the discussion of the relevant cases...'. ${ }^{91}$ 'There is no uniform mechanism to correct inconsistent decisions'. 92

However, the inconsistency of arbitration decisions is much related to the process of legal reasoning and methodology of arbitrations. It is a deficient of legal reasoning as a consequence of the obscure international law concept on the issues. Such as in regard of hierarchy of legal sources, whether it considered before or after the treaty itself. Equally, the existence of customary international law in regards of legitimacy and abstract claim of such sources is also obscure. Substantive change of the award can be found if arbitration can consider to accept other sources, and encourage themselves to create a new referendum.

Based on this contentious and different award on Argentina case, there might be three challenges arises: First: the argument of necessity interpretation has reflected mostly the idea of foreign investors that profit oriented which exclude the people necessity concern in Third World states. Second, it was not engaged with the root of economic crises of Argentina which was initiated by the reluctant of the IMF to reimburse the loan fund to bailout the financial crises due to the constrain of conditionality complying of Argentina. Thirdly, the absent of the assessment of economic development in order to justify the economic policy of Argentina to be justified as necessity would be regarded a failure of Human right regime to involve in international investment arbitration. ${ }^{93}$

\section{Toward a Purposive Approach}

The meaning of development as the right of state can support the interpretation of treaties in international law. Referring to article 31 of the Vienna convention on the Law of Treaties stated that "[a] treaty shall be interpreted in good faith in accordance with the ordinary meaning to be given to the terms of the treaty in their context and in the light of its object and purpose". The Tribunal also considered that, taking "a teleological approach" to the ICSID Convention, a tribunal ought to interpret the word "investment" so as to encourage, facilitate and promote cross-border economic cooperation and development. It held that support for this approach could be found, inter alia, in the Preamble to the ICSID Convention which speaks of "[c]onsidering the need for international cooperation for economic development...." 94

So, the meaning of economic development as a condition of the meaning of investment in the ICSID article 25 (1) refer to the preamble of the ICSID convention. The different interpretation between the original award that confirms 'the contribution to economic development' as a condition for defining the meaning of investment and the

90 Regarding the inconsistency of investment arbitration see Susan D. Franck, (2005) 'The Legitimacy Crisis in Investment Treaty Arbitration: Privatizing Public International Law Through Inconsistent Decisions', Fordham Law Review, Vol . 73, issue 4, p. 1521

91 Susan D. Franck, (2005) 'The Legitimacy Crisis in Investment Treaty Arbitration: Privatizing Public International Law Through Inconsistent Decisions', Fordham Law Review, Vol . 73, issue 4, p. 1546

92 Ibid.

93 See for example the United Nations Report of Human Right Council (fifteenth Session, 13 September -1 October 2010) General Assembly Official Record, Supplement No. 53 A (A/65/53/Add.1)

94 See Malaysia Historical Salvors Sdn Bhd v. The Government of Malaysia, Decision on the Application for Annulment, (ICSID Case no. ARB/05/10), para 14. 
annulment award which reject the former argument is grounded on the interpretation approaches between 'teleological' and 'semantic' approaches. The second thing is the absence of the word economic development in the article 25 (1) which made 'economic development in host states' becomes vaguer in the ICSID system.

The purposive approaches has been ever used by the government of Malaysia which argues "that "investment" under Article 25(1) of the ICSID Convention means an investment for the economic development of the host State, ...". 95 However, the semantic approach was used by the annulment award in the Malaysia Historical Salvors case confirmed that the contribution to the economic development of the host state is not considered as a condition of an investment in the ICSID. ${ }^{96}$ This award has rejected the previous award that places a contribution to economic development of host state is a condition of the investment in the ICSID. However in dissenting opinion, Judge Mohamed Shahabuddeen highlighted that economic development of host states is a condition of an ICSID investment. His argument based on:

(a). However wide is the competence of parties to determine the terms of an investment, that competence is subject to some outer limits outside of their will, if only to measure the width of their competence within those limits. (b). The outer limits in this case included a requirement that an investment must contribute to the economic development of the host State. (c). The Tribunal was correct in finding that the contribution to the economic development of the host State had to be substantial or significant. (d). The Tribunal was also correct in finding that the Applicant's outlay did not promote the economic development of Malaysia in a substantial or significant manner. (e). It is a reversal of the logical process to begin the inquiry with a consideration of what is an investment under the 1981 Agreement between the Government of the United Kingdom of Great Britain and Northern Ireland and the Government of Malaysia for the Promotion and Protection of Investments (the "BIT"). And, ( $f$ ), if the Tribunal erred in holding to these effects, it nevertheless did not manifestly exceed its powers. ${ }^{97}$

In this annulment awards, confirm that the ICSID system as it is based on the ICSID convention has difficulty to inspire 'a contribution to economic development' as a main grounding for the defining 'investment'. In this sense, TW state has a little chance to defence its economic development as a basis for any action toward the foreign investors in the ICSID framework. However, there is a space for economic development to get more appreciation in international investment system for the benefit of people In other words it can be said that to enforce the right of development and the right of sovereignty to be more obvious in practice and to the benefit of people in TW states. This was recognized by the Tribunal in Amco v. Indonesia when it concluded: "[t]hus, the Convention is aimed to protect, to the same extent and with the same vigour the investor and the host State, not forgetting that to protect investments is to protect the general interest of development and of developing countries" .98

95 Malaysia Historical Salvors Sdn Bhd v. The Government of Malaysia, Decision on the Application for Annulment, (ICSID Case no. ARB/05/10), para 43.

96 Malaysia Historical Salvors Sdn Bhd v. The Government of Malaysia, Decision on the Application for Annulment, (ICSID Case no. ARB/05/10).

97 See Malaysia Historical Salvors Sdn Bhd v. The Government of Malaysia, Decision on the Application for Annulment, (ICSID Case no. ARB/05/10). (dissenting opinion of judge Mohammed Shahabuddeen)

98 Amco Asia Corporation and others v. Republic of Indonesia, ICSID Case No. ARB/81/1, Decision on Jurisdiction, 25 September 1983 (“Amco v. Indonesia”). See also id., Award, 20 November 1984. 
The compensation for a nationalized asset should be paid in accordance with the ability of the new state, not by the principle of prompt, adequate and effective means because former colonies have seized the wealth of states. That was the argument delivered by Mochtar to win the Tobacco Bremen case in 1959.Decisions favouring the view that a contribution to economic development has to be substantial or significant are to be found in Joy Mining v. Egypt, L.E.S.I. - DIPENTA v. Algeria and so forth. 99

\section{Conclusion}

This paper highlighted that Argentina cases in the ICSID, which was originated to responding economic crisis in the country. It is essentially in line with the objective of the BIT and customary international law. Argentina's treaty law argument invokes the non-precluded measures (NPM) provisions of Argentine BIT that exempt certain actions taken by states in response to extraordinary circumstances from the substantive protections of the treaties. Meanwhile Argentina's customary International Law argument has asserted that the doctrine of necessity precludes the wrongfulness of Argentina's actions in response to the crisis.

The Argentina cases in the ICSID tribunal has placed a major essential defect of the argument which is beyond the objective of the BIT spirit. This has given a comprehensive way to assess Argentina case from the purpose of investment to the economic advancement and people interest in a state. It expands into a broader context of the meaning of International Law in purposive perspective; it can be developed the circle or the priorities of International Law objectives such as in the categorization of what is term essentials, complements and embellishment in the light of national development of a state. This formulation then can be used in settling the contradicted argument in international investment disputes.

\section{Acknowledgments}

Thanks to early comments from Dr. Vassilis P. Tzevelekos (University of Hull, UK) and unanimous reviewers for better formulation of this paper.

\section{References}

Books:

Bjorklund, A.K., (2008) 'Emergency Exceptions: State of Necessity and Force Majeure' in Peter Muchlinski et al., The Oxford Handbook of International Investment Law, Oxford: Oxford University Press.

August Reinisch, Necessity in Investment Arbitration in I.F. Dekker and E.Hey (eds.) Netherlands Year Book of International Law Vol. 41, 2010, The Hague, T.M.C. Asser Institute.

99 See similar argument in Joy Mining Machinery Limited v. Arab Republic of Egypt, ICSID Case No. ARB/03/11, Award on Jurisdiction, 6 August 2004 ("Joy Mining v. Egypt"), paras. 49, 53. Consortium Groupement L.E.S.I. - DIPENTA v. People's Democratic Republic of Algeria, ICSID Case No. ARB/03/8, Award, 10 January 2005, ("L.E.S.I. - DIPENTA v. Algeria"), Section II, para. 14(i) - (ii). 33 Bayindir Insaat Turizm Ticaret Ve Sanayi A.S. v. Islamic Republic of Pakistan, ICSID Case No. ARB/03/29, Decision on Jurisdiction, 14 November 2005 (“Bayindir v. Pakistan”), para. 137. See also Franz Volk v. S.P.R.L. Ets J. Vervaecke, 9 July 1969, 1969 European Court 00295, holding, on a question Calamity. 
Journal articles:

Aziz T. (2001) Saliba, Rebus Sic Stantibus: A Comparative Survey, E-Law Murdoch University Electronic Journal of Law, Vol. 8, No. 3, September 2001, hal.3.

Bishop R. Doak \& Luzi, Roberto Aguirre (2005) 'Investment Claims: First Lessons from Argentina' in Tod Weiler, International Invesment Law And Arbitration: Leading Cases From The ICSID, NAFTA, Bilateral Treaties And Customary International Law, London: Cameron May.

Burke-White, William W., "The Argentine Financial Crisis: State Liability Under BITs and the Legitimacy of the ICSID System" (2008). Scholarship at Penn Law. Paper 202. http://lsr.nellco.org/upenn_wps/202.

Cesar Augusto Bunge and Diego Cesar Bunge, 'The Jose De Costa Rica Pact and the Calve doctrine', the University of Miami Inter-American Law Review, Vol. 16 No.1 (spring, 1984).

Claudia Frutos-Peterson, LGEE Energy Corp., LGEE Capital Corp. and LGEE International Inc. v. Argentina Republic (ICSID Case No. ARB/02/1), introductory note, ICSID Review, Foreign Invesment Law Journal, p. 150-154

Crawford, J (2002) The International Law Commission's Article on State Responsibility: Introduction, Text And Comentaries, Cambridge : Cambridge University Press, article 20-25, p.160-186.

Daniel Chudnovsky and Andres Lopes, Foreign Investment and Sustainable Development in Argentina, Discussion Paper number 12, Working Group on Development and Environment in America, April 2008.

Documents of the Thirty-Second Session (1980), 2 Y.B. Int'1 L. Comm'n 14, U.N. Doc. A/

Federico Sturzenegger and Jeromin Zettle Meyer (2007) Debt Defaults and Lessons from A Decade of Crises, the IMT press.

Francesco Francioni, Access to Justice, Denial of Justice and international Investment Law, The European Journal of International Law (2009) Vol.20 no.3, 2009, 729, http://ejil.oxfordjournals.org/ accessed on November 7, 2012.

Frank Spoorenberg \& Jorge E.Vinuales, 'Conflicting Decision in International Arbitration', in The Law And Practice Of International Court And Tribunals 8 (2009) the Netherlands: Martinus Nijhoff Publisher, p. 91-113.

Giorgio Gogiashvili, "Clausula rebus sic stantibus : Dynamics and Statics in Law", Georgian Law Review 9/2006.

Hornbeck (2010) Argentina's Defaulted Sovereign Debt: Dealing with the "Holdouts", Congressional research service, January 21, 2010, www, crs.gov, accessed in 1 September 2011.

Ian Laird 'the emergency exception and the state of necessity' in Federico Ortino et al. (2007) Investment Treaty Law, Current Issues II, Nationality and Investment Treaty Claims, Fair and Equitable Treatment In Investment Treaty Law, London: British Institute of International and comparative Law, p. 237-251.

International Law Commission, Report of the International Law Commission: Draft Articles on the Responsibility of States for Internationally Wrongful Acts, U.N. Doc. A/56/10 (2001).

Kenneth J. Vandevelde, (1993) of Politics and Markets: The Shifting Ideology of the BITs, 11 INT'L TAX \& BUS. LAW. 159, 170. 
Matthias Scherer, ICSID Annulment Proceedings Based on Serious Departure from a fundamental Rule of Procedure, in Czech $\mathcal{E}$ Central European Yearbook of Arbitration.

Michael Waibel (ed) (2010)The Backlash Against Investment Arbitration, Perceptions and Reality, UK: Kluwer Law International.

MYA Kadir and A. Murray, (2019) "Resource Nationalism in the Law and Policies of Indonesia: A Contest of State, Foreign Investors, and Indigenous Peoples", Asian Journal of International Law.

MYA. Kadir, (2016) 'Application of the Law of Self-Determination in a Postcolonial Context: A Guideline', Journal of East Asia and International Law 9 (1).

MYA. KAdir, (2017) 'Hull Formula and Standard of Compensation for Expropriation in Postcolonial States', Kanun Jurnal Ilmu Hukum 19 (2), 231-248

Sahib Singh, Necessity in Investor-State Arbitration: The Sempra Annulment Decision, 16 August 2010, http://www.ejiltalk.org/necessity-in-investor-state-arbitration-the-sempraannulment-decision, [accessed on 15 November 2016].

Second Report on State Responsibility: Addendum, Int'l L. Comm'n, 51st Session, at 30, U.N. Doc. A/CN.4/498/Add.2 (1999).

Sornarajah, $\mathrm{M}$ "The Fair and Equitable Standard of Treatment: Whose Fairness? Whose Equity? In Federico Ortino et al. (2007) Investment Treaty Law, Current Issues II, Nationality And Investment Treaty Claims, Fair And Equitable Treatment In Investment Treaty Law, London: British Institute of International and comparative Law.

Sornarajah, M. (2004) the International Law on Foreign Investment, Cambridge: Cambridge University Press.

Stephan W. Schill, International Invesment Law and the Host State's Power to Handle Economic Crises, 24 Journal of International Arbitration 265 (2007).

Susan D. Franck, (2005) 'The Legitimacy Crisis in Investment Treaty Arbitration: Privatizing Public International Law Through Inconsistent Decisions', Fordham Law Review, Vol . 73, issue 4.

Sweet, Alec Stone, (2013) "Investor-State Arbitration: Proportionality's New Frontier" (2010). Faculty Scholarship Series. 69. http://digitalcommons.law.yale.edu/fss_papers/69, assessed on 15 November 2013.

The United Nation Charter 1945.

Treaty between United States of America and the Argentine Republic Concerning the Reciprocal Encouragement and Protection of Investment 1991, Article IV (3).

UNIDROIT principle of international commercial contract 2010 in http://www.unidroit.org/english/principles/contracts/principles2010/blackletter2010english.pdf, assessed in 15 November 2010.

United Nations Report of Human Right Council (fifteenth Session, 13 September -1 October 2010) General Assembly Official Record, Supplement No. 53 A (A/65/53/Add.1)

Vassilis P. Tzevelekos, (2000), The Use of Article 31(3)(c) of the VCLT in The Case Law of the ECTHR: an Effective Anti-Fragmentation Tool or a Selective Loophole for the Reinforcement of Human Rights Teleology? Between Evolution and Systemic Integration, Michigan Journal of International Law, Vol. 31, Spring 2010. 
Weiniger, M., "the standard of compensation for violation of the fair and equitable treatment standard" in Federico Ortino et al. (2007) Investment Treaty Law, Current Issues II, Nationality And Investment Treaty Claims, Fair And Equitable Treatment In Investment Treaty Law, London: British Institute of International and comparative Law.

Website:

http://icsid.worldbank.org/ICSID/FrontServlet?requestType=CasesRH\&actionVal=L istCases, last updated November 24, 2011, [accessed on 26 November 2016].

http://www.business-humanrights.org/media/documents/ruggie/ruggie-guidingprinciples-21-mar-2011.pdf. [accessed on 15 November 2016].

Responsibility of States for Internationally Wrongful Acts, General commentary, accessed on 12 November 2011 at http://untreaty.un.org/ilc/texts/instruments/english/commentaries/9_6_2001 pdf. p. 80. [accessed on 15 November 2016].

Sahib Singh , The Enron Annulment Decision's exposure of Necessity's Endemic Uncertainty: A Welcome Critique, 25 October 2010, in http://www.ejiltalk.org/the-enronannulment-decision \%E2\% 80\%99s-exposure-of-necessity\%E2\%80\%99s-endemicuncertainty-a-welcome-critique/\#more-2732, [accessed on 15 November 2016].

Cases:

Amco Asia Corporation and others v. Republic of Indonesia, ICSID Case No. ARB/81/1, Decision on Jurisdiction, 25 September 1983 ("Amco v. Indonesia"). See also id., Award, 20 November 1984.

CMS Gas Transmission Co $v$ the Argentina Republic, ICSID ARB/01/8 (Award) May 12 2005, para. 317, available at $h t t p: / / w w w . w o r l d b a n k . o r g / i c s i d / c a s e s / C M S \_$Award.pdf.

CMS Gas Transmission Company $\mathrm{v}$ the Argentina republic, (ICSID case No. ARB /01/8)(Annulment Proceeding), 25 September 2007 on Decision of the Ad Hoc Committee on the application for Annulment of the Argentina Republic. Para.158.

CMS Gas Transmission Company v. the Republic of Argentina (ICSID case No.ARB/01/8), decision of the tribunal on objections to Jurisdiction, of July 17, 2003.

Continental Casualty Company v. Argentine Republic (ICSID Case No. ARB/03/9) (Award) 5 September 2008, para. 168.

Enron Corp and Ponderosa Assets, L.P. v. Argentina Republic (ICSID case No. $\mathrm{ARB} / 01 / 3)$, decision on Jurisdiction of January 14, 2004.

Enron Corp and Ponderosa Assets, L.P. v. Argentina Republic (ICSID case No. ARB/01/3), decision on Jurisdiction (Ancillary Claim) of August 2, 2004, para. 32.

Enron Corp et al $v$ The Argentina Republic, (ICSID Case no ARB/01/3(Award), 22 May 2007, http://ita.law.uvic.ca/documents/EnronAward.pdf.

Enron Creditors Recovery Corp. Ponderosa Assets, L.P. v. The Argentina Republic (ICSID Case No. ARB/01/3) (Annulment Proceeding) 30 July 2010, para. 377. Accessed on $15 \quad$ November 2011 from http://italaw.com/documents/EnronAnnulmentDecision.pdf.

Joy Mining Machinery Limited v. Arab Republic of Egypt, ICSID Case No. ARB/03/11, Award on Jurisdiction, 6 August 2004 ("Joy Mining v. Egypt"), paras. 49, 53.

LG EE Energy Corp., LGEE Capital Corp., LGEE International, Inc v Argentine Republic (ICSID Case No.ARB/02/1, Award) July 25, 2007, para.2-3. 
LGEE Energy Corp., LGEE Capital Corp., LGEE International Inc. v. The Argentina Republic, ICSID Case No. ARB/02/1, Decision on Liability, 3 October 2006, 46 International Legal Materials 40 (2007).

LGEE Energy Corp., LGEE Capital Corp., LGEE International Inc. v. The Argentina Republic (ICSID Case No. ARB/02/1(Decision On Liability) October 3, 2006, paras. $201-266$.

Malaysia Historical Salvors Sdn Bhd v. The Government of Malaysia, Decision on the Application for Annulment, (ICSID Case no. ARB/05/10). (dissenting opinion of judge Mohammed Shahabuddeen)

Sempra Energy Int $v$ Argentina, (ICSID case No. ARB/02/16 (Award) para.346-355, 28 September 2007), http://ita.law.uvic.ca/documents/SempraAward.pdf. [accessed December 12, 2018)

Sempra Energy International v. Argentina Republic (ICSID Case No. ARB/02/16) (Annulment Proceeding) on 29 June 2010, para. 160-165.

\section{Conflict of Interest Statement:}

The author(s) declares that the research was conducted in the absence of any commercial or financial relationships that could 